\title{
A study of palm oil mill processing and environmental assessment of palm oil mill effluent treatment
}

\author{
Azam Akhbari ${ }^{1+}$, Prashad Kumaran Kutty ${ }^{2}$, Onn Chiu Chuen ${ }^{1}$, Shaliza Ibrahim ${ }^{1,3^{\dagger}}$ \\ ${ }^{1}$ Department of Civil Engineering, Faculty of Engineering, University of Malaya, Kuala Lumpur 50603, Malaysia \\ ${ }^{2} J$ ugra Palm Oil Mill Sdn Bhd, Sungai Buaya, 42700 Banting, Selangor, Malaysia \\ ${ }^{3}$ Institute of Ocean and Earth Sciences (IOES), University of Malaya, Kuala Lumpur 50603, Malaysia
}

\begin{abstract}
This work discusses the palm oil mill processing carried out at Jugra Palm Oil Mill Sdn Bhd, situated at Selangor, Malaysia with the capacity of 45-t fresh fruit bunch (FFB)/h. Typically, oil palm residues and palm oil mill effluent (POME) from FFB are generated while processing. Prior to discharge, POME should be treated to remove pollutants in the effluent. As such, the performances of anaerobic and aerobic ponds were assessed in this study to determine temperature, $\mathrm{pH}$, biological oxygen demand (BOD), sludge volume index (SVI), and dissolved oxygen (DO). From the experiments, mesophilic temperature due to better process stability was applied in anaerobic ponds. The $\mathrm{pH}$ results displayed a fluctuating trend between lower control limit and upper control limit, and, the $\mathrm{pH}$ value increased from one pond to another. The final discharge BOD and SVI appeared to be lower than $100 \mathrm{mg} / \mathrm{L}$ and $10 \mathrm{~mL} / \mathrm{L}$ indicating low degree of pollution and good settling ability for biomass/solid. DO was close to normal, mostly below $2 \mathrm{mg} / \mathrm{L}$. The experimental outcomes revealed the effective treatability of POME in adherence to the standard regulation, which is the priority for environmental sustainability within this industry domain.
\end{abstract}

Keywords: Anaerobic digestion, Fresh fruit bunch, Palm oil mill effluent

\section{Introduction}

Palm oil being the world's most promptly growing and essential vegetable oil in tropical climate such as Indonesia and Malaysia, has made these countries to flourish in natural resources with significant economic value [1]. Several steps are incorporated in palm oil mill processing plant, to extract the palm oil from the fresh fruit, including sterilization, bunch stripping, and fresh fruit bunch (FFB), to name a few steps [2]. The total land under palm oil cultivation for year 2017 hit almost 5.77 million hectares (ha) (one hectare of oil palm produced between 10 and- 35 tons FFB per year), indicating $2.23 \%$ of the arable acreage in Malaysia. The lifecycle of oil palm is over $200 \mathrm{y}$, whereas the productive life is approximately 20-25 y. The plant market is between 11 and 15 mon, while the first harvest can be carried out after 32-38 mon of planting [3]. The peak yield of palm oil takes 5-10 y, which is about $45-56 \%$ of FFB. The mesocarp of the fruit is used to generate oil. Almost $40-50 \%$ of the yield is from kernel. Both kernel and mesocarp of the fruit generate approximately $17 \mathrm{t} / \mathrm{ha} . \mathrm{y}$, in which
1 ton of crude palm oil (CPO) can be generated from 5.8 tons of fresh fruit bunch (FFB) [4]. The progression of this industry has vastly contributed to the economy, along with environmental pollution, mainly due to the oil extraction process that generates a significant amount of by-products, including oil palm trunks (OPT), oil palm fronds, empty fruit bunch (EFB), palm pressed fibres, palm kernel shells and palm oil mill effluent (POME) [5]. Discharge of these by-products and effluents into the environment causes adverse effects and environmental pollution. Malaysia has become a prominent producer of POME at the global arena with approximately 50 million tons of production at annual rate [6]. POME is characterised by high organic acid content, carbohydrate, minerals, and proteins that makes this waste source a suitable nutrient for growth of biomass [7]. In particular, POME refers to a waste product that is harmful to be discharged into the environment prior to treatment process. Aerobic and anaerobic methods can be applied to treat POME [8]. In aerobic digester, oxygen is used during the procedure. Due to the high growth rate of microorganisms in aerobic condition, lower retention time is required
This is an Open Access article distributed under the terms of the Creative Commons Attribution Non-Commercial License (http://creativecommons.org/licenses/by-nc/3.0/) which permits unrestricted non-commercial use, distribution, and reproduction in any medium, provided the original work is properly cited.
Received December 27, 2018 Accepted March 7, 2019

$\dagger$ Corresponding author

Email: aazam.akhbari@yahoo.com,shaliza@um.edu.my Tel: +603-7967-4643

Copyright (C) 2020 Korean Society of Environmental Engineers 
to promote anaerobic digestion. This anaerobic digestion technique has been widely applied in treating POME due to its high production rate with low energy consumption and flexibility in using a wide range of organic wastes enriched with carbohydrates including waste molasses [9], dairy wastewater [10], sewage sludge [11], and POME $[12,13]$. This process is composed of three reactions: hydrolysis, acidogenesis, and methanogenesis [14]. During the hydrolysis process, fermentative bacteria convert complex organic compounds to monomers, such as amino acids, monosaccharides and fatty acids. In the second stage, simple monomers are degraded to hydrogen, carbon dioxide and acetate which serve as originators to produce methane in the third process [15]. Anaerobic digestion is suitable for highly polluted wastewaters due to high amount of COD, low production of surplus sludge, and the potential of generating energy [16].

Despite the high efficiency of this process, stabilization of ample organic matter cannot be achieved in many applications, mainly due to the strength of wastewater. Hence, the final effluent generated from anaerobic digestion is appropriate for aerobic pond ,especially for further treatment process to meet discharge standard [17]. With that, this study presents an overview of the most critical stages in the palm oil mill industry of Jugra Palm Oil Mill (JPOM), situated at Selangor, Malaysia. This study assessed the effect of several critical process parameters including temperature, $\mathrm{pH}$, biological oxygen demand (BOD), sludge volume index (SVI), and dissolved oxygen (DO), on the operational performance of wastewater treatment plant to attain a standard range of discharge into the environment.

\section{Palm Oil Production Process}

The milling industry consists of a number of unit processes to extract palm oil from FFB. The process flow diagram of CPO and kernel plant processing is illustrated in Fig. 1. Some major palm oil mill process is provided in the following sections.

\subsection{Sterilization}

The FFBs are sterilized to inactivate hydrolytic enzymes in order to inhibit the formation of free fatty acids, hence generating high quality $\mathrm{CPO}$. The minimum temperature required to halt the enzymes activities ranges from $55^{\circ} \mathrm{C}$ to $140^{\circ} \mathrm{C}$ for $75-90 \mathrm{~min}$. In this phase, the fruitlets are loosened from the FFB. Adequate steam into the system is essential to get the right sterilized fruit and high-quality production. Steam from the steam receiver is supplied to each sterilizer at $2.72 \mathrm{~atm}$. In fact, this mill uses three peaks of processing for the FFB, signifying that air and condensate water are discharged in three-cycle times. The time within discharge for the first two cycles is $30 \mathrm{~min}$ and the final discharge depends on the ripeness of fruit, which is classified into normal ripe, under-ripe and overripe that are heated at for 85, 85 and 75 min, respectively. Poorly heated fruit can affect the thresher performance and result in poor separation of seeds from bunches, thus affecting oil extraction rate (OER). This factory operates the process with four units of sterilizer to support the production rate of $45 \mathrm{t} / \mathrm{h}$. Each sterilizer fills eight cages with a capacity of 2.8 ton per cage.

\subsection{Thresher}

In the thresher, FFB is rotated until it exits from the thresher in the form of fruitless bunches and fruits. The speed of thresher is adjusted to one that is moderate. Next, the fruits are delivered into a digester, while the empty bunches are conveyed to empty bunch cutter for further processing. Before delivering the empty bunches to the empty bunch plant, it passes through a second thresher. If the fruit remains as a bunch, it is sent to the thresher again. Hence, three threshers are available with one constantly kept on standby.

\subsection{Digester}

After that, the fruits are blended with steam to mesh the fruit so as to ensure that the fruits are smooth for pressing when delivered to screw press. The blade that rotates inside the digester during operation meshes the fruit. Steam is applied to support the meshing process in the digester. Five digesters are available with one kept on standby.

\subsection{Screw Press}

Here, meshed fruit is pressed to yield oil. The screw press equipment has two worms and a press. The worms resemble screws that rotate in opposite direction of each other and pull the fruit from the digester so that it reaches the press through the worm. The presses work at $7.04 \mathrm{~kW}$ to ensure that the fruit is completely pressed and no nut is broken. Hot water is used to flow the oil from pressing process to oil clarification section. Leftover fruits without content are passed via oil to kernel plant. Five screw presses are available in this factory, with one kept on standby.

\subsection{Oil Clarification Section}

In this section, oil with sludge obtained from screw press is flown to oil clarification section. First, oil is delivered into the first sand filter that is positioned in horizontal at $1.5 \mathrm{~m}$ height. Oil is mixed with sand, mud and other types of sludge. Next, in the heavy phase, sand and mud are settled and light phase, such an oil remains at the upper surface. When it overflows, only oil at the upper part is flown out. Sand and mud are drained at the bottom. Oil that press through the vibrating screen is pumped into a huge vertical clarifier tank (10 m height and $4 \mathrm{~m}$ diameter). It is a big tank with a height of $10 \mathrm{~m}$ and diameter $4 \mathrm{~m}$. In this tank, steam is used to heat the oil up to $85^{\circ} \mathrm{C}$ to $90^{\circ} \mathrm{C}$. Pure oil stays at the top layer, while sludge at the bottom. The top layer oil is collected in a pure oil tank using a skimmer, and then, transferred into vertical purifiers that contain 90 cone-shaped disks inside. The purifier discards dirt from oil. When it rotates, dirt flows between the disks and oil is transferred into a vacuum dryer. The pressure in the vacuum dryer is high at approximately $0.9 \mathrm{~atm}$ to eliminate moisture in the oil. After that, pure oil is pumped into a storage tank and ready to be sold. The major wastes at this stage are decanter wastewater and decanter cake. Along with sludge from the separator, decanter flows into the sludge pit before it is transferred into wastewater treatment plant. Cakes are sold as animal food and used 


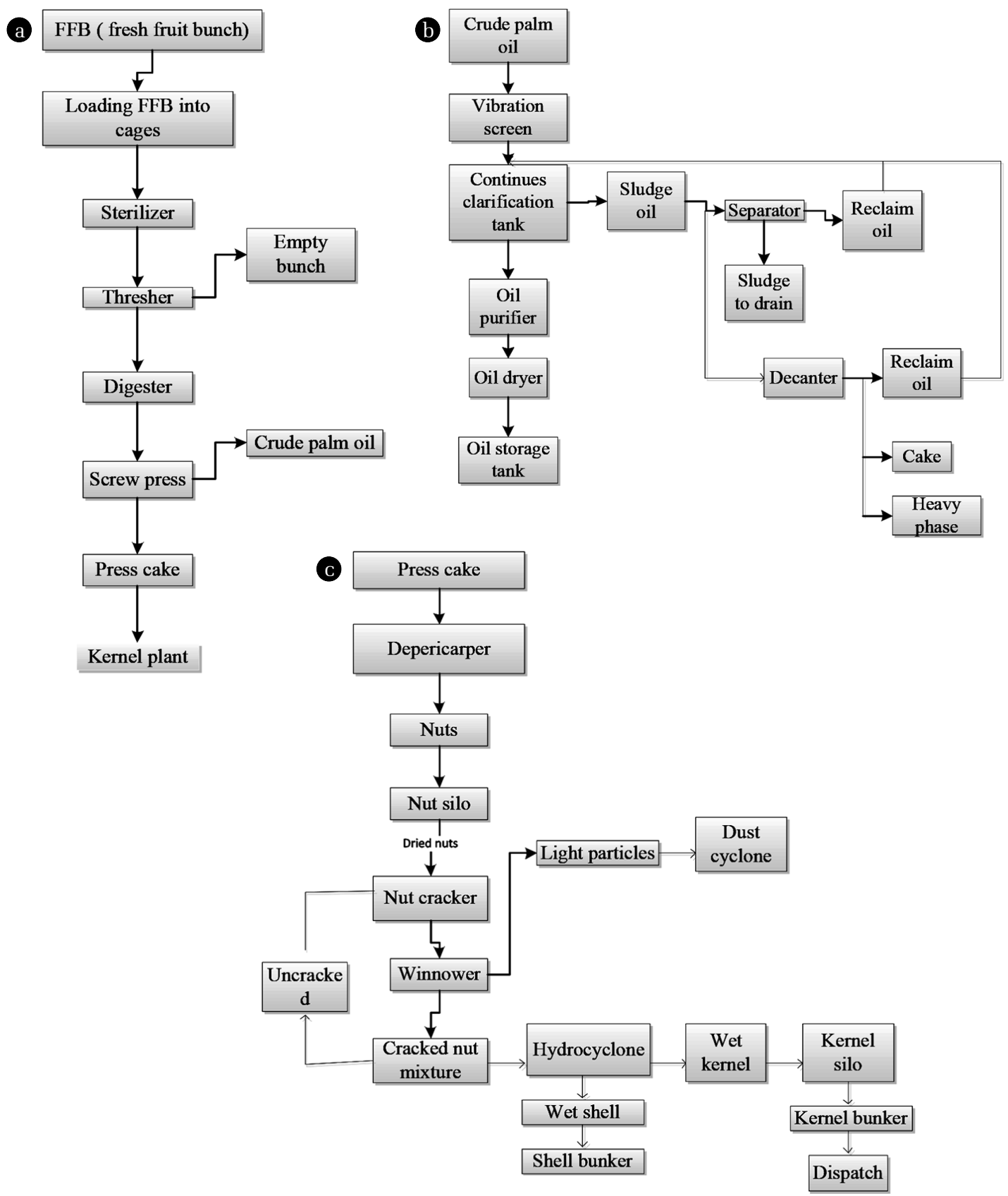

Fig. 1. Flow charts of (a) initial process of FFB, (b) processing of FFB to produce CPO and (c) process flow for kernel plant.

as compounds to make fertilizers.

\subsection{Kernel Plant}

In this step, further processing of the CPO is carried out. Leftover fruits from screw press including nuts and fibres, are delivered to the kernel plant. Fruits with additional mesh are called 'cake breaker', whereas leftover fruits are known as 'mesocarp' or 'fibre'. Cake breakers are used roughly to separate fibre from nuts. At the end of cake breaker, fibre cyclone at top and nut polishing drum at the bottom are installed. Fibre cyclone is used to pull up the fibre to the cyclone. Light particles are drained and fibre gets settled. The primary concept of fibre cyclone. Next, fibre is transferred to boiler as boiler fuel. At the end of cake breaker process, only fibres are moved up while nuts move downwards to the nut polishing drum. In this section, the nuts rotate in. The condition in the drum is airy because the fibre cyclone fan is sucks the air from the nut-polishing drum. The nuts are collected at the nut bunker. Subsequently, the nuts go through vibrating feed in order, to control the nuts that are moved from bunker into destoner. Destoner is applied to separate stone, steel, screw 
Table 1. POME Characteristics

\begin{tabular}{lccc}
\hline Parameter & Concentration & Regulatory discharge limits & Unit \\
\hline Temp & $80-90$ & 40 & ${ }^{\circ} \mathrm{C}$ \\
$\mathrm{pH}$ & $5 \pm 0.2$ & $6-9$ & $\mathrm{mg} / \mathrm{L}$ \\
Oil and grease (O\&G) & $4,000 \pm 20$ & 100 & $\mathrm{mg} / \mathrm{L}$ \\
Biological oxygen demand (BOD) & $25,000 \pm 1,000$ & 50 & $\mathrm{mg} / \mathrm{L}$ \\
Chemical oxygen demand (COD) & $50,000 \pm 2,000$ & - & $\mathrm{mg} / \mathrm{L}$ \\
Total solid (TS) & $40,000 \pm 1,000$ & 50 & $\mathrm{mg} / \mathrm{L}$ \\
Total suspended solid (TSS) & $18,000 \pm 500$ & - & $\mathrm{mg} / \mathrm{L}$ \\
Total volatile solid (TVS) & $34,000 \pm 800$ & - & $\mathrm{mg} / \mathrm{L}$ \\
NH3-N & $35 \pm 1$ & - & $\mathrm{mg} / \mathrm{L}$ \\
TKN & $750 \pm 5$ & - & $\mathrm{NTU}$ \\
Turbidity & $664 \pm 4$ & & \\
\hline
\end{tabular}

and other impurities contained in the nut bunker. In the next step, a ripper mill is used to crack the nut to get the kernel. This equipment has a cylinder rod and rotates at a certain rpm. The cracking process is performed when the nuts go through the cylinder rod. The rotation is controlled to avoid the kernel from cracking, and hence, kernel loss. From the ripper mill, kernel and shell are mixed. Hydro cyclones are used to separate the kernel from the shell. When kernel and shell are transferred into the cyclone, it is rotated with water. In water, the kernel rises and the shell is washed over by water. Finally, both shell and kernel are sold.

\subsection{Empty Bunch Plant}

This plant is responsible for further processing of empty bunches. The analysis revealed that oil storage in empty bunch was about $4 \%$, indicating profit upon extraction. Thus, this company has designed and installed an empty bunch plant to extract oil. Empty bunches from thresher are transferred to empty bunch press cutter. Here, the empty bunches are cut into small pieces, pressed to extract liquid called jus that contains about $4 \%$ oil. Next, the oil is transferred to oil clarification section to be mixed with oil generated from screw press. This factory is the first in Malaysia to have built empty bunches cutter and press.

\subsection{Evaporators Plant}

The evaporator is applied to generate POME from the final sludge. This equipment has been built to minimize emission of final effluent into wastewater treatment plant. The principle reflects the following; first, final slurry from the sludge pit is pumped into a retention tank and then pumped into the evaporator. Next, the sludge is recycled in the evaporator for $90 \mathrm{~min}$. After that, steam flows into the evaporator at a rate of $13 \mathrm{t} / \mathrm{h}$, while the vacuum is at 8.15 $\times 10^{-5} \mathrm{~atm}$. This process is continued until sludge becomes more dense. The moisture content for POME is about $80 \%$ from the final sludge. Steam and vacuum pressure are applied to absorb the moisture content from the sludge during the recycling process. The moisture is cooled down using a cooling tower that generates condensation water from moisture in sludge and condensed steam. This water is used to clean the evaporator. The complete operation is controlled automatically via panel board. The entire process carried out in JPOM (Malaysia) and the flow diagram of mass balance for 10-ton FFB/h is displayed in Fig. 1 and Fig. S1, respectively. In this procedure, the rate of FFB processing based on one ton per hour had been considered as the mill industry capacity. As for this particular case study, the capacity of the mill was 45-ton $\mathrm{FFB} / \mathrm{h}$. The boiler was fabricated to provide a maximum rating of $35,000 \mathrm{~kg} / \mathrm{h}$ with outlet steam pressure of $29.6 \mathrm{~atm}$ and steam temperature at $250^{\circ} \mathrm{C}$. The shell, the fibre and the EFB were used as fuel for boilers. In this mill industry, one ton of FFB produces $230 \mathrm{~kg}$ of EFB, 1,925 kg of fibre, as well as $310 \mathrm{~kg}$ of shell and dust, as portrayed in the flow diagram. Hence, for $45 \mathrm{t} \mathrm{FFB/} \mathrm{h}$ mill, 86,625 $\mathrm{kg}$ of fibre, as well as $13,950 \mathrm{~kg}$ of shell and dust, are produced. The overall net loss for this process is estimated at $12 \%$ relative to FFB, as displayed in the flow diagram in Fig. S1.

\section{9. $P O M E$}

Based on the quality of the production process in palm oil mills, characterization of POME may differ. The overall characteristics of raw POME and the regulatory discharge limits are presented Table 1. POME is produced from various processing units in an oil mill industry including clarification of sludge, sterilization of condensates, hydro cyclone drain-off, boiler blowing down, tank and decanters. The four primary stages categorized by Sethupathi [18] for POME production are sterilization of FFB, clarification of the extracted CPO, hydrocyclone, and separation of cracked mixture of kernel and shell. It has been estimated that 0.5-0.75 ton of POME can be produced from one ton of palm fruit bunches which contains $5 \mathrm{~kg} / \mathrm{t}$ organic matter [19]. This discharge as raw or partially treated of the palm industry has high content of degradable organic matter that may adversely affect the environment [20]. Since no chemical is added during the oil extraction process, this discharge is evaluated as a non-toxic effluent. Nevertheless, due to depletion of DO, it has been considered as one of the main pollutants for aquatic life. Therefore, prior to being discharged into the environment, this particular effluent should be treated in adherence to several standards of the Federal Environmental Protection Agency, World Health Organization (WHO); Department of Petroleum Resources refined, etc. The wastewater treatment plant that is located $1.5 \mathrm{~km}$ from the factory supports the sludge produced for a load of 45 ton per hour. The plant has dual lines starting with cooling pond, pre-treatment pond, anaerobic pond, aerobic pond, and holding pond. Sludge 
water from the industry enters into the cooling pond to reduce its temperature and retention time for oil to surface and easy to collect. Next, CPO is filled on the surface of the pond. After that, the sludge water is transferred to pre-treatment pond before entering anaerobic and aerobic lagoons. In the anaerobic pond, degradation of complex organic wastes generate $\mathrm{CH}_{4}, \mathrm{CO}_{2}$, and $\mathrm{H}_{2} \mathrm{O}$, while in the aerobic pond, aerobes bacteria convert organic waste into biomass and $\mathrm{CO}_{2}$ [17]. The sludge water is held for $30 \mathrm{~d}$ before the next process. In the aerobic pond, sprinklers are installed to provide sufficient oxygen to the bacteria. Next, the treated water is held for nine days before being discharged into the environment.

\section{Analytical Methods}

The concentrations of COD, BOD, total Kjeldahl nitrogen (TKN), $\mathrm{pH}$, Mixed liquor suspended solids (MLSS), volatile suspended solids, Oil and Grease (O\&G), Total solids (TS), Total volatile solids (TVS), and $\mathrm{NH}_{3}-\mathrm{N}$ of the system were measured by using standard methods for the characterization and examination of water and wastewater [21]. For COD, a colorimetric method with a closed reflux technique using spectroquant termoreactor (tr 420 Merck, Darmstadt, Germany) was used. For BOD, and DO a portable BOD/DO meter (HANNA, HI 98193), Hanna Instruments (M) Sdn Bhd, Malaysia. Spectrophotometer (pharo 100, Merk, Germany) at $600 \mathrm{~nm}$ was used to measure the absorbance of COD samples. Total Kjeldahl nitrogen (TKN) was determined by TKN meter Gerhardt model (vapodest10, C. Gerhardt GmbH \& Co. KG Cäsariusstr. 97 D-53639 Königswinter). The pH meter model pH 700 (EUTEC instruments, Singapore) was used to measure the $\mathrm{pH}$. Turbidity was measured by a ProDSS 4-port digital sampling system, YSI-USA. Shaker incubator (lab tec, DAIHAN IABTEC Co, LTD, Korea), was used for incubation.

\section{Results and Discussion}

\subsection{Performance Monitoring of POME Treatment System (POMETS)}

The JPOM treatment system has been designed to operate at a capacity of $60 \mathrm{t} \mathrm{FFB/h}$. Effluent from the mill is treated using the pond system. A total of nine ponds are available at the JPOM effluent treatment plant, which are: acidification/cooling pond (2 units), anaerobic pond (4 units), and aerobic/aeration pond (3 units). The two primary sources of POME from the mill are raw POME from oil room and steriliser condensate. Untreated effluent BOD level has the average of $46,400 \mathrm{mg} / \mathrm{L}$, whereas the final discharge BOD is reduced to below $100 \mathrm{mg} / \mathrm{L}$ before it is discharged into water sources. The maximum amount of FFB processed in Jugra mill is about 1,000 t FFB/d. Effluent is generated based on a factor of 0.65 (processed FFB) t/h. Hence, the maximum effluent produced in day is approximately $650 \mathrm{t} / \mathrm{d}$. The flow chart for JPOM effluent treatment plant is illustrated in Fig. S2.

Anaerobic digestion is the most important conventional method that appears to be practical for POME treatment due to its high organic content. Organic biodegradable materials are degraded to methane and carbon dioxide as biogas via three primary steps, which are: hydrolysis, acidogenesis, and methanogenesis. During the hydrolysis process, acidogenesis bacteria are used to break hydrogen gas, carbon dioxide, acetates, and volatile fatty acids (VFA) into organic materials. Next, methanogenesis bacteria produce methane gas. Both acidogenesis and methanogenesis processes demand varying $\mathrm{pH}$ and temperature values for process controlling, as further elaborated in the following section. Another essential factor is hydraulic retention time (HRT), wherein POME is maintained in both anaerobic and aerobic pond systems for digestion process. The HRT and BOD level of the final discharge after treatment in anaerobic and aerobic ponds were calculated and tabulated Table 2 .

\subsection{Discussion of Performance Monitoring Results}

\subsubsection{Temperature}

Digesting temperature is the basis parameter of the microbial population existence, particularly the variety of the methanogen community in the anaerobic pond [22]. Bacteria in the anaerobic pond are susceptible to their environmental temperature. There are two common temperature levels used in the conventional anaerobic digestion, which are mesophilic bacteria and thermophilic bacteria active in the range of $35-40^{\circ} \mathrm{C}$ and $55-60^{\circ} \mathrm{C}$, respectively [23].

Most of the anaerobic process is done in the mesophilic condition due to more stable process and lower energy consumption compared to the thermophilic condition. Moreover, microbial diversity decreases with increasing temperature in anaerobic pond, which would negatively affect process performance [24]. Therefore, a various microbial population is projected under a mesophilic condition,

Table 2. Calculation of HRT and BOD of the Anaerobic and Aerobic Ponds

\begin{tabular}{lcc}
\hline & Anaerobic treatment stage & Aerobic treatment stage \\
\hline Total volume of the ponds $\left(\mathrm{m}^{3}\right)$, (anaerobic 4 ponds and aerobic 3 ponds) & 102,200 & 35,700 \\
\hline Input BOD level to anaerobic stage $(\mathrm{mg} / \mathrm{L})$ & 46,400 & 811 \\
\hline Hydraulic retention time for anaerobic stage (day) & 157 & 55 \\
\hline Output BOD level (mg/L) after anaerobic treatment is determined by using & & 39 (final discharge) \\
the first-order kinetic formula & 811 (output) \\
$\mathrm{Li}=$ Input BOD level of effluent & & \\
$\mathrm{k}=$ Constant value of 0.358 & & \\
$\mathrm{t}=$ Hydraulic retention time & & \\
$\left(\mathrm{Li} / 1+K_{t}\right)$ &
\end{tabular}


which could be advantageous to degrade several types of organic matters [25]. In this monitoring stage, two daily data from the

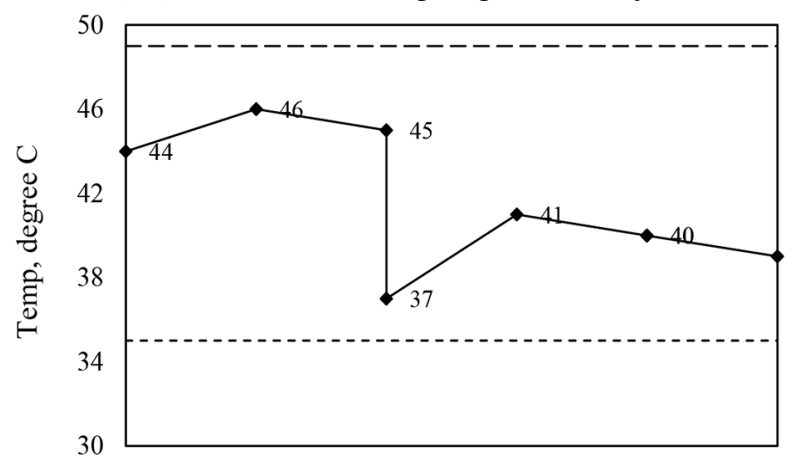

2017-01-04 2017-01-05 2017-01-06 2017-01-07 2017-01-08 2017-01-09

$$
\text { ----- LCL ---- UCL —-Tem }
$$

Fig. 2. The raw effluent temperature in cooling pond 2.

start until middle of six months' operation were analysed to assess the performance. It should be noted that the raw POME effluent temperature was approximately $85^{\circ} \mathrm{C}$, decreased after being transferred into the two cooling ponds. The graph in Fig. 2 shows the temperature trend in the second cooling pond outlet before entering the anaerobic pond. It was noted that temperatures in April and May 2017 were higher than the rest. Cooling pond outlet temperature found to be most of the time above $40^{\circ} \mathrm{C}$ but did not exceed upper control limit (UCL) $49^{\circ} \mathrm{C}$. Failure to control temperature rise can cause biomass washout of VFA accumulation because of inhibition of methanogenesis. At high temperatures, VFA production is higher compared to mesophilic condition [26]. Hence, these mill operators
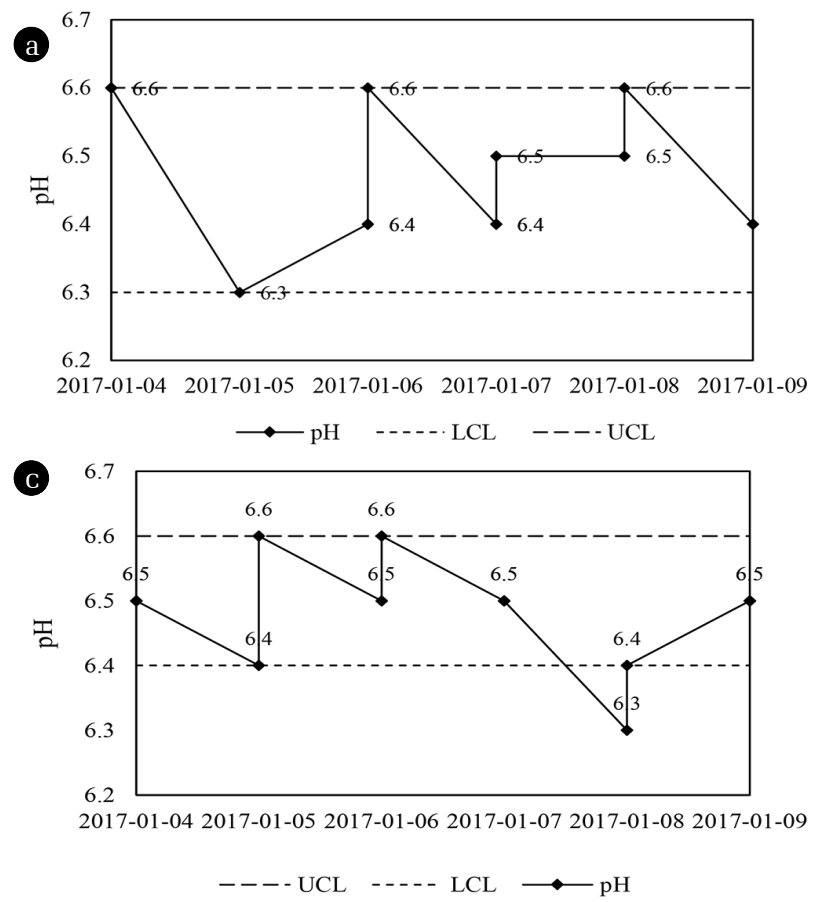

Fig. 3. $\mathrm{pH}$ variation trend of $\mathrm{POME}$ in anaerobic ponds: a) $A_{1}$, b) $A_{2}$, c) $B_{1}$, and d) $B_{2}$. prefer to have digesters operating in mesophilic temperature due to better process stability.

\subsection{2. $\mathrm{pH}$}

The $\mathrm{pH}$ of anaerobic pond has been reckoned as one of the most significant operational parameters that heavily affect the metabolic pathways of anaerobic bacteria, especially methanogens bacteria. Methanogenesis is affected by $\mathrm{pH}$. As such, methanogenic activity will decline when $\mathrm{pH}$ in the pond deviates from the optimum value. Optimum $\mathrm{pH}$ for most microbial growth is between 6.5 and 7.5. When the $\mathrm{pH}$ drops below 6.5, methanogens bacteria becomes inactivated and unable to convert all VFA into methane and other by-products [27]. Increased VFA leads to a drop in the $\mathrm{pH}$ of the pond and this worsens the situation. Hence, monitoring the $\mathrm{pH}$ value is crucial for every anaerobic pond and prompt remedial action should be taken to sustain the physical condition of the pond. Variation of $\mathrm{pH}$ in anaerobic pond is influenced by buffering capacity, which primarily refers to bicarbonate and carbon dioxide. The simultaneous presence of bicarbonate and ammonia, which are by-products of methanogenesis activity, causes a buffer formation state in the anaerobic pond, hence providing proper buffering capacity. This ammonium bicarbonate, which is alkaline, enhances the $\mathrm{pH}$ of raw POME (4 to 5) and maintains the $\mathrm{pH}$ of pond to almost neutral [28]. As such, a correct balance line should be maintained between acidogenesis and methanogenesis activities by anaerobic bacteria in maintaining the $\mathrm{pH}$ of pond at almost constant. Low $\mathrm{pH}$ reading in anaerobic pond is not operationally appropriate and quick action is demanded. First, feeding of POME into this pond should be stopped or minimised. Second, recycling seed sludge from proper $\mathrm{pH}$ pond should be flowed back to the inlet of the pond that faces the distraught condition. Recycling
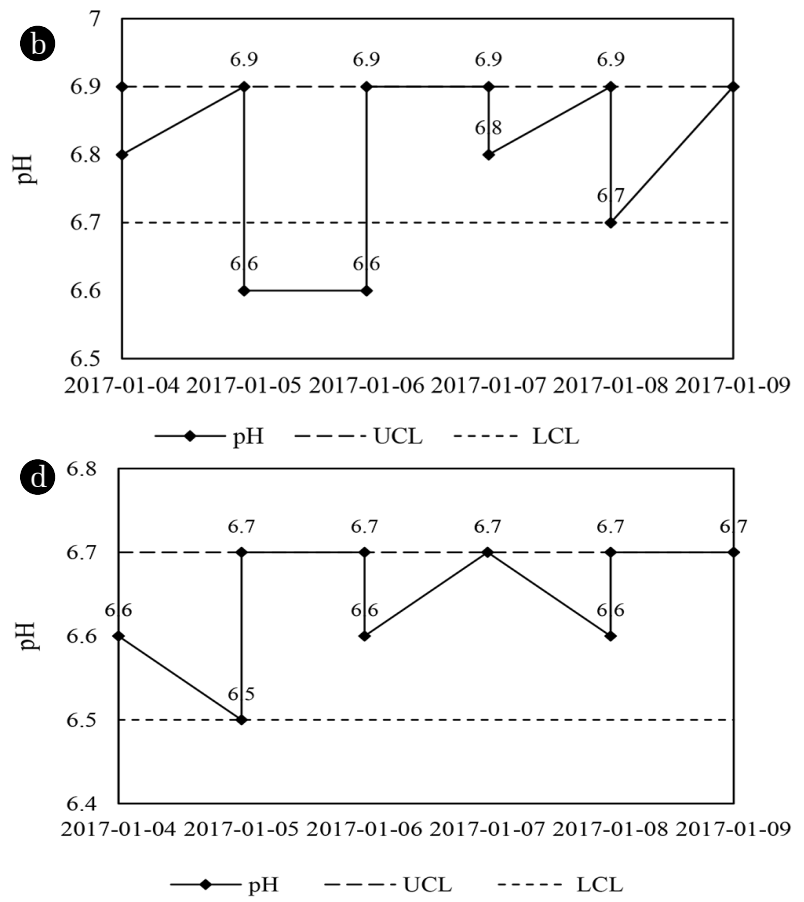
must be done until the $\mathrm{pH}$ of the troubled pond improves to a normal level. Next, raw POME can be fed into the pond with close monitoring of its $\mathrm{pH}$. The $\mathrm{pH}$ results of the anaerobic ponds are presented in Fig. 3. Two daily data were selected from the start until middle of the month. The $\mathrm{pH}$ of anaerobic pond $\mathrm{A}_{1}$ shown in Fig. 3(a) was satisfactory during the period of study except in mid May 2017. It can be seen that $\mathrm{pH}$ dropped to 6.3 and attained lower control limit (LCL). High loading of POME into this pond led to a drop in the $\mathrm{pH}$ value. The $\mathrm{pH}$ for anaerobic pond $\mathrm{A}_{2}$ was also relatively unstable. In mid-May 2017, and early June 2017, the pH level was below LCL as exhibited in Fig. 3(b). This result is attributable to the sudden increase in FFB processing. It is emphasised here that the $\mathrm{pH}$ of UCL, as given in the graph, could lead to food starvation amongst the anaerobic bacteria if the $\mathrm{pH}$ exceeds this level. As displayed in Fig. 3(c), the $\mathrm{pH}$ for anaerobic pond $B_{1}$ appeared suitable at the time of study, except in early August 2017, in which the $\mathrm{pH}$ level was lower than LCL at 6.3. High loading of POME into this pond decreased the $\mathrm{pH}$. August 2017 also witnessed processing of high volume FFB. Based on Fig. $3(\mathrm{~d})$, the $\mathrm{pH}$ for anaerobic pond $\mathrm{B}_{2}$ was steady and stable during most of the test period. The $\mathrm{pH}$ in the beginning displayed the most stable trend at LCL level, while a fluctuating trend was observed from May until September at UCL level. In short, the $\mathrm{pH}$ value increased from one pond to another.

\subsubsection{BOD}

The BOD is defined as the amount of oxygen used by microorganisms to which biologically decompose organic matter in wastewater within specified time and temperature. The more massive the organic content is, the higher is the oxygen demand to decompose organic matter, thus causing relatively higher BOD outcomes [29]. Two daily data were selected from start until middle of the six months' operation in order to study the BOD of the ponds, as well as to assess reliable data for operative management in light of wastewater quality. Fig. 4 shows the BOD for the studied anaerobic ponds. The anaerobic pond is the primary treatment stage and reduces the organic load in the wastewater. A series of four with effluent being transferred from the anaerobic pond to the facultative pond
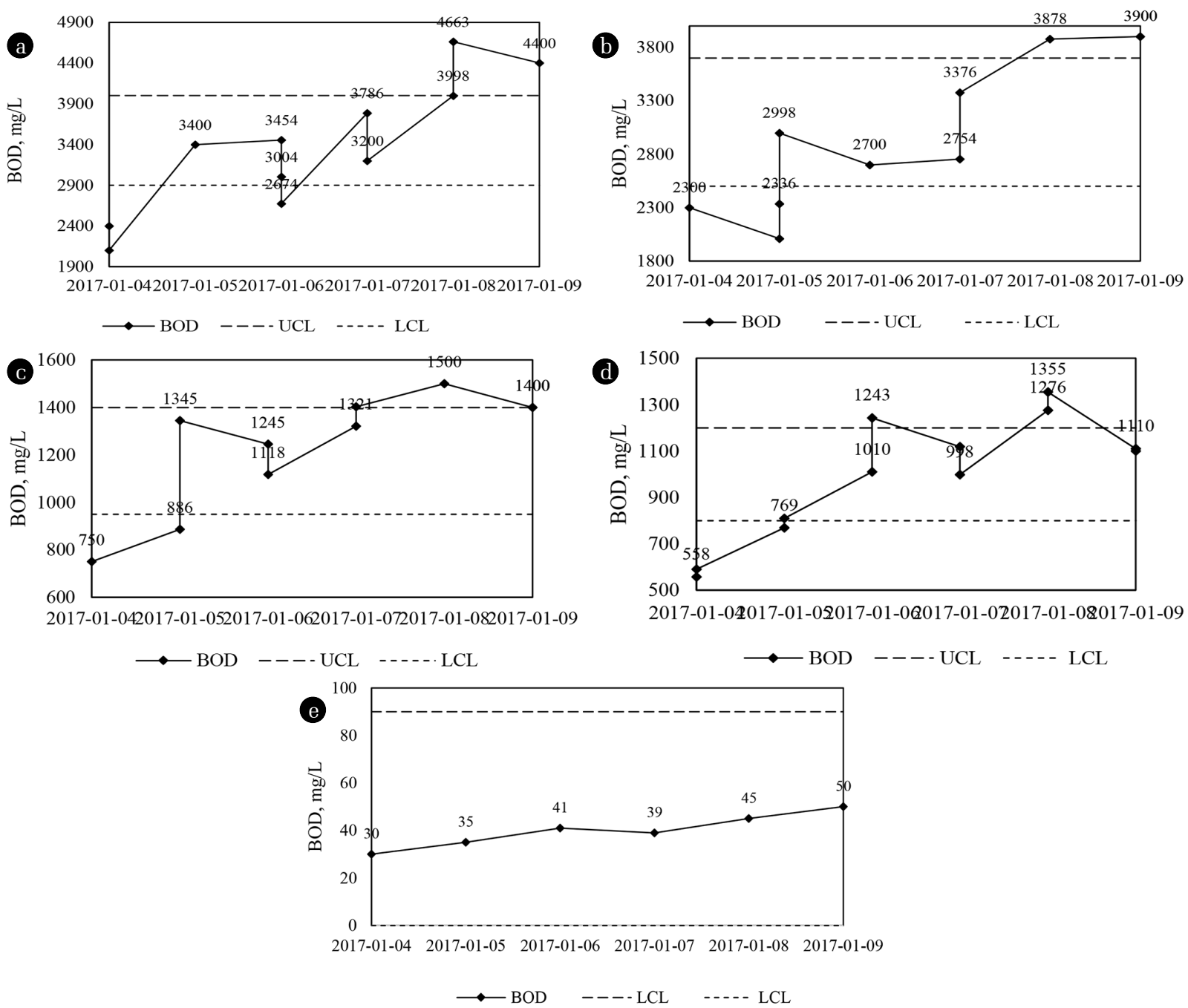

Fig. 4. $B O D$ variation trend of POME in anaerobic ponds: a) $A_{1}$, b) $A_{2}$, c) $B 1$, d) $B 2$, and e) final discharge. 
and, finally, to the aerobic pond. Fig. 4(a) shows that the BOD for pond $A_{1}$ was acceptable at the time of study, except during mid-August and early September 2017, in which the BOD level exceeded UCL (2,769-4,151 mg/L).

Remaining BOD in effluent after treatment in an anaerobic pond transferred to the second anaerobic pond. Next, Fig. 4(b) indicates that the BOD results for anaerobic $\mathrm{A}_{2}$ pond were suitable for early September 2017, but the BOD exceeded UCL (2,567-3,679 mg/L) in August-September due to the higher processing of FFB that extended the processing hours. Fig. 4(c) illustrates the trend for BOD in anaerobic pond $\mathrm{B}_{1}$ had been satisfactory during the monitoring period, except in August and September 2017. The BOD reading for the two months exceeded UCL (689-1,500 mg/L). Fig. 4(d) exhibits a similar trend for anaerobic pond $\mathrm{B}_{2}$. High POME was produced due to peak crop season, which demanded extended milling hours. Hence, High loading of POME into this pond increased the amount of BOD. Anaerobic bacteria in these four ponds convert organic carbon into methane and through this process, remove up to $60 \%$ of the BOD (558-1,355 mg/L). The effluent from the anaerobic pond is transferred to the aerobic ponds. In aerobic treatment ponds, aerobic microorganisms use DO to degrade the organic matter into carbon dioxide, water and cell biomass. In this pond, BOD reductions of up to $95 \%$ and decrease in the concentration of nutrients and pathogens in effluent happened. It is evident from Fig. 4(e) that the BOD for final discharge in aerobic pond 2 was well-controlled during the period of evaluation and all the reading values were below UCL $(100 \mathrm{mg} / \mathrm{L})$. It is apparent that, while the anaerobic ponds seem to be unable to reduce the pollutant concentration for most of the operating conditions below the standard limits of $100 \mathrm{mg} / \mathrm{L}$ for BOD and aerobic pond will enable the concentration of pollutants to be reduced to well below such limits. In such cases the effluent can be safely discharged into rivers without further treatment. Hence, the effluent was able to meet the discharge standard of BOD.

\subsubsection{SVI}

In the biological reactor such as the aeration tank, the microorganisms biochemically convert organic matter contained in POME to carbon dioxide, water, energy and biomass. The next significant step is to separate biomass from mixed liquor which occurs in the aerobic pond. The biomass (sludge) should have good settling properties to efficiently separate from solid and to clear the final effluent discharge. The SVI refers to a measure of the settling ability characteristic of the biomass. A smaller SVI value displays better settling property of the sludge [30]. The SVI test adheres to a simple procedure that uses a $1,000 \mathrm{~mL}$ measuring cylinder filled with the sample of mixed liquor. The data on settled sludge volume after $30 \mathrm{~min}$ and suspended solid were used to compute the SVI, wherein SVI below $50 \mathrm{~mL} / \mathrm{g}$ signifies good settling ability of the mixed liquor. Fig. 5(a) exhibits that the result was below $50 \mathrm{~mL} / \mathrm{g}$, which shows remarkable SVI. Next, Fig. 5 (b) $B_{1}$ shows that the SVI reading for all ponds were below $30 \mathrm{~mL} / \mathrm{g}$. The highest SVI was recorded for the first aerobic pond, $A_{1}$. Based on Fig. 5(c), the final discharge of SVI appeared to be lower than $10 \mathrm{~mL} / \mathrm{g}$ most of the time, indicating good settling ability for biomass/solid in aerobic ponds. The settleability and compactness of activated sludge are directly related to floc structure. The floc structure is the key factors in determining the SVI, which further affecting the biological removal efficiency [31]. Hence, the results obtained shows the
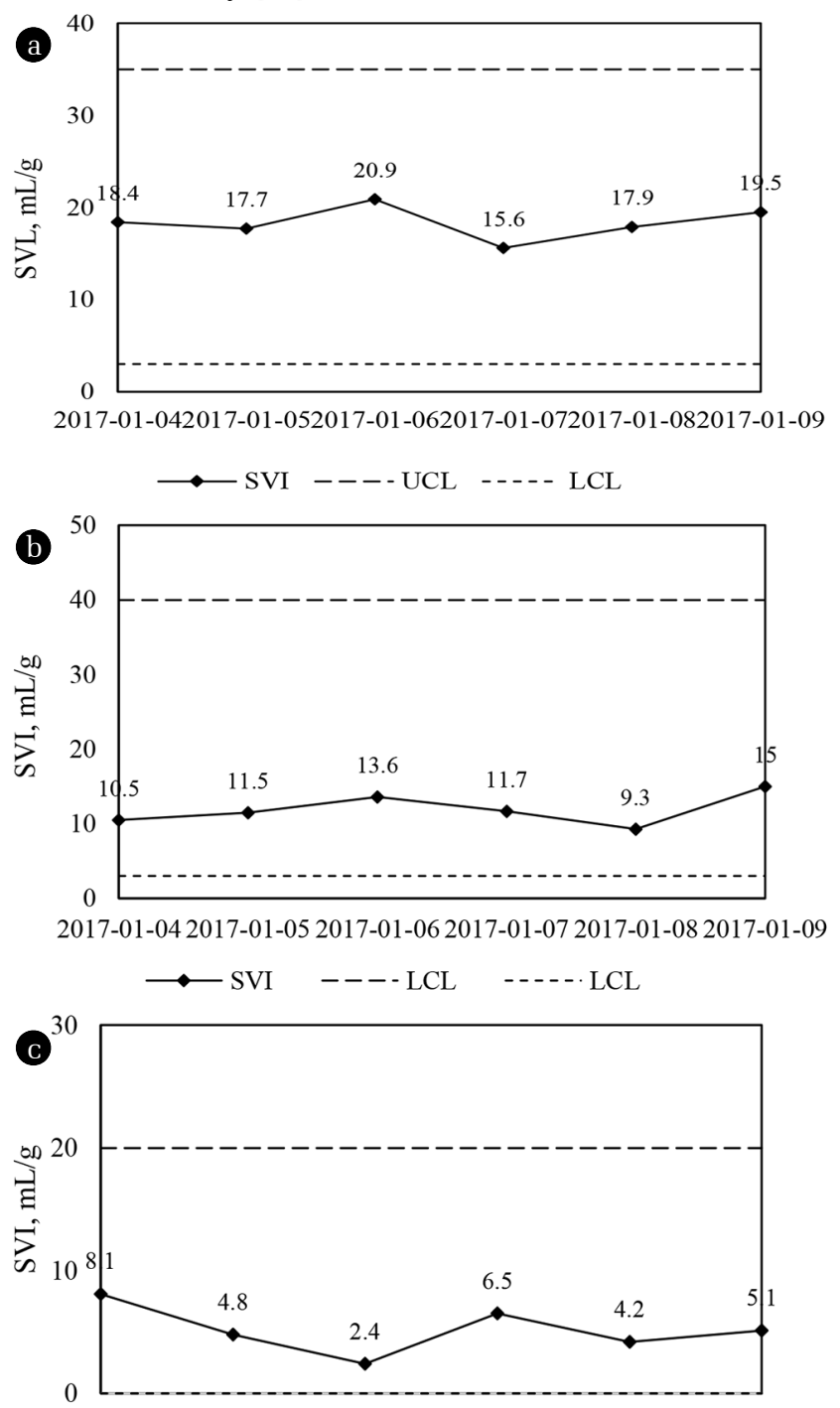

2017-01-04 2017-01-05 2017-01-06 2017-01-07 2017-01-08 2017-01-09

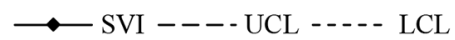

Fig. 5. SVI variation trend of sludge in aerobic ponds: a) $A_{1}$, b) $B_{1}$, and c) $\mathrm{A}_{2}$.

improvement of the ability of the sludge to settle and compress resulted in decreasing SVI.

\subsubsection{DO}

The DO is one of the most critical measurements parameters in aerobic biological treatment system [32]. Aerobic bacteria require DO to live and carry out microbiological activities. Two daily data selected from the start until middle of six months' operation were used to assess the performance outcomes. Wastewater may contain various concentrations of DO. The DO level recorded for the entire aerobic pond was analysed. The levels in aerobic ponds $A_{1}, B_{1}$ and $A_{2}$ are displayed in Fig. 6(a)-(c), respectively, which seemed normal as it was mostly below $2 \mathrm{mg} / \mathrm{L}$. 
The DO concentration in pond $\mathrm{A}_{1}$ is low and fluctuated from 0.4 to $1.4 \mathrm{mg} / \mathrm{L}$. This phenomenon was attributable to the high

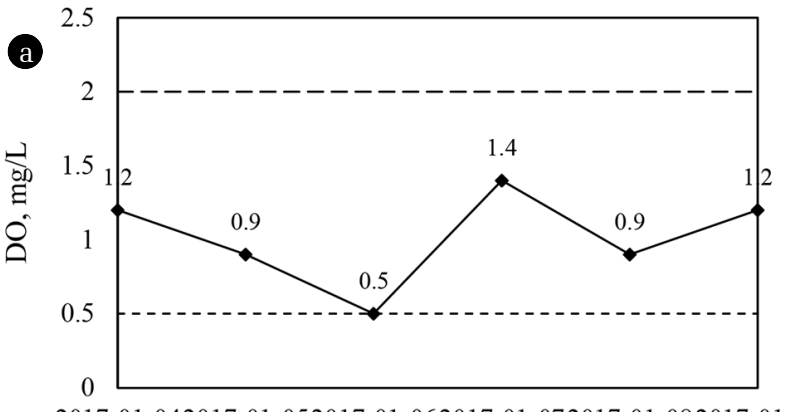

2017-01-042017-01-052017-01-062017-01-072017-01-082017-01-09

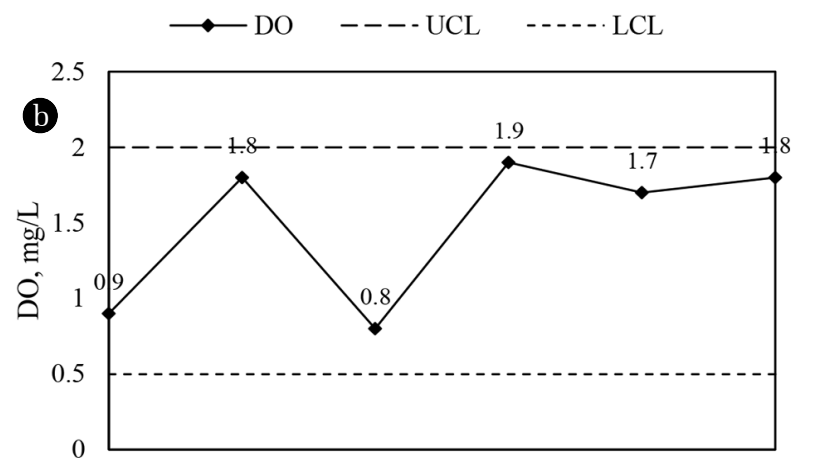

2017-01-04 2017-01-05 2017-01-06 2017-01-07 2017-01-08 2017-01-09

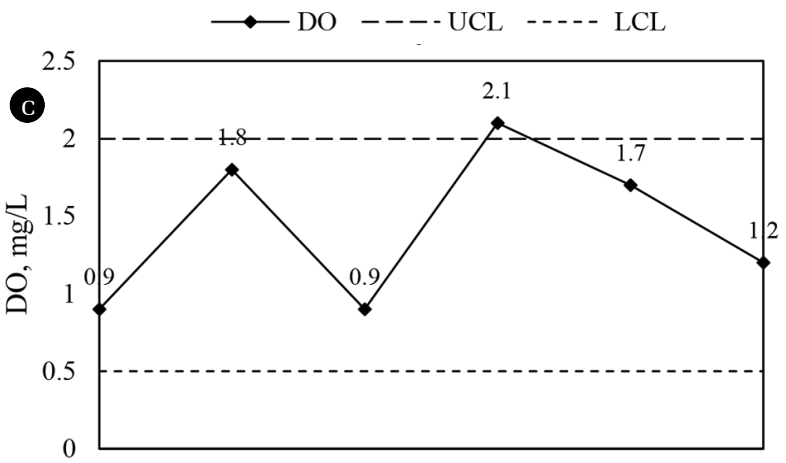

2017-01-04 2017-01-05 2017-01-06 2017-01-07 2017-01-08 2017-01-09

$$
\longrightarrow \text { DO - - - UCL -.-.-. LCL }
$$

Fig. 6. DO variation trend of aerobic ponds: a) $A_{1}$, b) $B_{1}$, and c) $A_{2}$.

organic loadings in this pond which caused the DO to be effectively consumed by the degraders. Two surface aerator units were installed at aerobic ponds $A_{1}$ and $B_{1}$ to enhance the aeration process.

\section{Conclusions}

This research investigated the processes involved in palm oil mill by conducting a case study of JPOM, situated at Selangor, Malaysia. The mill performance with capacities of $45 \mathrm{t} / \mathrm{h}$ and 1,000 t/d FFB had been examined. In this mill industry, one ton of FFBs produced $230 \mathrm{~kg}$ of EFB, $1,925 \mathrm{~kg}$ of fibre, as well as $310 \mathrm{~kg}$ of shell and dust. Therefore, for 45 tons of FFB/h mill, 86,625 $\mathrm{kg}$ of fibre and
$13,950 \mathrm{~kg}$ of shell and dust were produced. The overall net loss for this process was estimated at $12 \%$ relative to FFB. Effluent generated from the mill was treated via anaerobic and aerobic pond systems. Due to the rising waste production, nine ponds have been used at JPOM as effluent treatment plant, inclusive of acidification/cooling pond ( 2 units), anaerobic pond ( 4 units), and aerobic/aeration pond (3 units). BOD for final discharge reduced from $46,000 \mathrm{mg} / \mathrm{L}$ to below $100 \mathrm{mg} / \mathrm{L}$ prior to being discharged into water sources. By controlling the effective parameters of the pond system in an efficient manner, this industry has been thriving in the environmental monitoring aspect waste management by treating POME in accordance to standard regulations.

\section{Acknowledgments}

The authors gratefully acknowledge the Research Council of Malaya University for the financial support [Grant. Number: RU019D-2014A; RU007C-2017J; RK005-2016; 57-02-03-1038] and any assistance and contribution rendered towards the preparation of this paper. Also, the authors would like to acknowledge everyone at Jugra Palm Oil Mill Sdn Bhd.

\section{References}

1. Yusoff S. Renewable energy from palm oil-innovation on effective utilization of waste. J. Clean. Prod. 2006;14:87-93.

2. Mahlia TMI, Abdulmuin MZ, Alamsyah TMI, Mukhlishien D. An alternative energy source from palm wastes industry for Malaysia and Indonesia. Energ. Convers. Manage. 2001;42: 2109-2118.

3. Sheil D, Casson A, Meijaard E, et al. The impacts and opportunities of oil palm in Southeast Asia: What do we know and what do we need to know? In: CIFOR Occasional Paper; 2009; Bogor: No.51.

4. Rupani PF, Singh RP, Ibrahim MH, Esa N. Review of current palm oil mill effluent (POME) treatment methods: Vermicomposting as a sustainable practice. World Appl. Sci. J. 2010;11:70-81.

5. Dalimin MN. Renewable energy update: Malaysia. Renew. Energ. 1995;6:435-439.

6. Awalludin MF, Sulaiman O, Hashim R, Nadhari WNAW. An overview of the oil palm industry in Malaysia and its waste utilization through thermochemical conversion, specifically via liquefaction. Renew. Sust. Energ. Rev. 2015;50:1469-1484.

7. Wu TY, Mohammad AW, Jahim JM, Anuar N. A holistic approach to managing palm oil mill effluent (POME): Biotechnological advances in the sustainable reuse of POME. Biotechnol. Adv. 2009;27:40-52.

8. Akhbari A, Zinatizadeh AA, Vafaeifard M, Mohammadi P, Syirat ZB, Ibrahim S. Effect of operational variables on biological hydrogen production from palm oil mill effluent by dark fermentation using response surface methodology. Desalin. Water Treat. 2019;137:101-113.

9. Guo W-Q, Ren NQ, Wang X-J, et al. Biohydrogen production from ethanol-type fermentation of molasses in an expanded granular sludge bed (EGSB) reactor. Int. J. Hydrog. Energ. 
2008;33:4981-4988.

10. Mohan SV, Babu VL, Sarma P. Effect of various pretreatment methods on anaerobic mixed microflora to enhance biohydrogen production utilizing dairy wastewater as substrate. Bioresour. Technol. 2008;99:59-67.

11. Cai M, Liu J, Wei Y. Enhanced biohydrogen production from sewage sludge with alkaline pretreatment. Environ. Sci. Technol. 2004;38:3195-3202.

12. Mohammadi P, Ibrahim S, Annuar MSM, Khashij M, Mousavi SA, Zinatizadeh A. Optimization of fermentative hydrogen production from palm oil mill effluent in an up-flow anaerobic sludge blanket fixed film bioreactor. Sust. Environ. Res. 2017;27:238-244.

13. Akhbari A, Ibrahim S, Zinatizadeh AA, et al. Evolutionary prediction of biohydrogen production by dark fermentation. CLEAN-Soil Air Water 2019;47:1700494.

14. Donoso-Bravo A, Retamal C, Carballa M, Ruiz-Filippi G, Chamy $\mathrm{R}$. Influence of temperature on the hydrolysis, acidogenesis and methanogenesis in mesophilic anaerobic digestion: Parameter identification and modeling application. Water Sci. Technol. 2009;60:9-17.

15. Oren A. Anaerobic degradation of organic compounds at high salt concentrations. Antonie van Leeuwenhoek 1988;54:267-277.

16. Reijnders L, Huijbregts M. Palm oil and the emission of carbon-based greenhouse gases. J. Clean. Prod. 2008;16:477-482.

17. Chan YJ, Chong MF, Law CL, Hassell DG. A review on anaerobic-aerobic treatment of industrial and municipal wastewater. Chem. Eng. J. 2009;155:1-18.

18. Sethupathi S. Removal of residue oil from palm, oil mill effluent (POME) using chitosan [disstertation]. Malaysia: Univ. Sains; 2004.

19. Yacob S, Shirai Y, Hassan MA, Wakisaka M, Subash S. Start-up operation of semi-commercial closed anaerobic digester for palm oil mill effluent treatment. Process Biochem. 2006;41:962-964.

20. Lam MK, Lee KT. Renewable and sustainable bioenergies production from palm oil mill effluent (POME): Win-win strategies toward better environmental protection. Biotechnol. Adv. 2011;29:124-141.

21. American Public Health Association, American Water Works
Association, Water Pollution Control Federation, \& Water Environment Federation. Standard methods for the examination of water and wastewater (Vol. 2). American Public Health Association; 1915.

22. Choong YY, Chou KW, Norli I. Strategies for improving biogas production of palm oil mill effluent (POME) anaerobic digestion: A critical review. Renew. Sust. Energ. Rev. 2018;82:2993-3006.

23. Oles J, Dichtl N, Niehoff H-h. Full scale experience of two stage thermophilic/mesophilic sludge digestion. Water Sci. Technol. 1997:36:449-456.

24. Kundu K, Sharma S, Sreekrishnan TR. Effect of operating temperatures on the microbial community profiles in a high cell density hybrid anaerobic bioreactor. Bioresour. Technol. 2012;118:502-511.

25. Chae KJ, Jang AM, Yim SK, Kim IS. The effects of digestion temperature and temperature shock on the biogas yields from the mesophilic anaerobic digestion of swine manure. Bioresour. Technol. 2008;99:1-6.

26. Poh PE, Chong MF. Development of anaerobic digestion methods for palm oil mill effluent (POME) treatment. Bioresour. Technol. 2009;100:1-9.

27. Chen Y, Cheng JJ, Creamer KS. Inhibition of anaerobic digestion process: A review. Bioresour. Technol. 2008;99:4044-4064.

28. Lin J, Zuo J, Gan L, et al. Effects of mixture ratio on anaerobic co-digestion with fruit and vegetable waste and food waste of China. J. Environ. Sci. 2011;23:1403-1408.

29. Igwe J, Onyegbado C, Abia A. Adsorption isotherm studies of BOD, TSS and colour reduction from palm oil mill effluent (POME) using boiler fly ash. Eclética Química 2010;35:195-208.

30. Liu Y-Q, Moy B, Kong YH, Tay JH. Formation, physical characteristics and microbial community structure of aerobic granules in a pilot-scale sequencing batch reactor for real wastewater treatment. Enzyme Microb. Technol. 2010;46:520-525.

31. Leong ML, Lee KM, Lai SO, Ooi BS. Sludge characteristics and performances of the sequencing batch reactor at different influent phenol concentrations. Desalination 2011;270:181-187.

32. Boopathy R. Factors limiting bioremediation technologies. Bioresour. Technol. 2000;74:63-67. 